\title{
SYLVIA TOWNSEND WARNER AND TUDOR CHURCH MUSIC
}

\begin{abstract}
Richard Searle
In a letter to the composer Herbert Howells written in February 1918 (Warner, 1918), Warner likened her situation at meetings of the editorial committee for Tudor Church Music (TCM) as akin to Susannah among the Elders. This analogy was not meant to imply that her musical colleagues posed her any threat; she was twentythree when the work of the informal committee began, some twenty years younger than her fellow editors and she must have felt signally their junior. Younger she may have been but, by virtue of her advanced musicological skills enabling her to read, interpret, score and augment the earliest sixteenth-century choral polyphony, she was more than their equal. It was Dr. Richard Terry, organist and choirmaster at Westminster Cathedral, who had tutored her in those skills, who had inspired her, developed and nurtured her, and made her erudition indispensable to the TCM project.
\end{abstract}


When Terry took up his cathedral post in 1903, he specifically concerned himself with establishing a high standard of choral singing and to this end he scored musical works from among the forgotten and unpublished manuscript part-books of Elizabethan and earlier music in the British Museum. His choir achieved considerable success and such was the excellence of choral singing it attracted an avid following, awakening awareness of Tudor polyphonic music among the wider church-going public. One of those who went to hear the Westminster choir was the renowned musician, writer on music and educationalist, Sir Henry Hadow. Hadow recognised that sixteenth-century music was of comparable standing to the poetry and drama of that age. He was aware also that the financial generosity of the Carnegie United Kingdom Trust (hereafter referred to as 'the Trust') could extend to unpublished British music and he took it upon himself to approach them to secure funding to publish the music being rediscovered by Terry. Hadow's informal proposal was taken up by the Trust's Executive Committee in February 1916. Terry's purpose was to make the music accessible through performance; Hadow identified a potential for making the music more widely known through publication.

Initially, it was proposed that Terry alone, the leading authority on polyphony, with most in-depth knowledge of sixteenth-century notation, should undertake the work over a period of five years: he would edit the music of two major composers, John Taverner (c.1495-1545) and William Byrd (1543 - 1623). To avoid competition and probable conflict with established music publishers, the Oxford University's Clarendon Press would be approached to publish the music. From the outset, it was intended that the music should be issued in two distinct and separate forms: a comprehensive, scholarly edition and a popular edition of individual musical works for practical performance at singing competition festivals and by amateur and professional choirs. It was wartime and the Trust acknowledged that publication would have to wait until the war was over. 
Once Terry had accepted the undertaking he realised that he would require assistance. He and Percy Buck were friends and, without substantiated documentary evidence to support it, we must assume that Buck introduced Warner to Terry as a budding composer to whom he had taught music at Harrow School; someone with a first class intellect who could reliably devote herself to learning and assimilating the specialist knowledge needed, and with time on her hands to pursue it. Although the exact date is unrecorded, Terry recruited Warner during the middle of 1916 and she began studying early Tudor manuscripts with him at the British Museum. She learned quickly, acquiring complete understanding of the notational complexities of the music sufficient to be able to score works unaided.

Sixteenth-century music, both religious and secular, was produced as separate part-books, one voice per book on a single stave for that voice alone, (Figure 1) unlike later music where all the voice parts and/or instrumental parts are scored: that is, they are all laid out below each other on the same page. A complete sixteenth-century work for several voices could comprise as many as six part-books, depending on the number of voices to be employed. Printed music was exceptional; each part-book had been copied by hand from its composer's manuscript. For large cathedral and collegiate choirs, ten part-books made up a complete set written for five voices: typically soprano (or treble), one or two altos, one or two tenors and a bass. Choirs were divided into two groups across the choir stalls: cantoris on the north side, and the decani, on the south side. Frequently, passages in the music were marked either cantoris or decani; to be sung by that group of singers alone.

The original music would have born little resemblance to that with which Warner was familiar prior to her engagement with Terry. Early music had largely been written on parchment - before about 1420 - and the notation defined in solid black shapes. With the introduction of paper, musical notes had to be written in outline, to avoid ink absorption. There were no bar lines 
to regulate the number of metrical beats to each group of musical notes on the stave; time signatures such as they were related to the breve (then the basic unit of musical time) and its subdivisions; key signatures, to indicate the number of sharps and flats, were not introduced till the eighteenth century. Other written notational symbols, some relating to the way choristers should sing the music, but excluding dynamics and expression marks, needed to be interpreted. But here is not the place to explore sixteenth-century notation, its intricacies and complexities, the rules and conventions, in detail. Warner wrote at length on most aspects of this subsequently, and Terry will no doubt have instilled in her that in Tudor times

music was still a craft, and its composers craftsmen, who followed mediaeval tradition in jealously guarding the mysteries of their craft. Consequently their notation was the province of the initiate, and was not intended to be intelligible to the multitude.

(Terry, 1920, pp.186)

By the time Warner started work with him, Terry had begun travelling to other collections of Tudor music: the Bodleian Library and Christ Church College in Oxford, as well as libraries in Cambridge, Durham, Edinburgh and Glasgow, among others. Travelling was costly both financially (although out-of-pocket expenses were paid) and in time; time that could otherwise be devoted to editorial matters. Terry requested unsuccessfully the purchase of a rotograph machine (a form of photocopier that could photographically reproduce documents as reverse positives - white text on a black background). Once manuscripts were 'rotographed', the copies could be taken home for study rather than having to travel to distant libraries in order to work on them. However, an arrangement was made with the Clarendon Press to use a rotograph machine in their possession and the colleges and cathedrals were persuaded to transfer temporarily 
their precious and principally unique documents, despite it being wartime, into the safe custody of the Clarendon Press to be copied: an unbelievable occurrence in the present day.

Terry submitted a progress report to the Carnegie Trustees covering the period June to December 1916 in which he identifies locations where pertinent manuscripts could be found. By now his brief had broadened from the British Museum's holdings of Taverner and Byrd to publishing the liturgical works of all the significant Tudor composers (Carnegie GD 281/41/225). Terry also drew attention to two valuable voluntary assistants, one of whom was Cecie Stainer ${ }^{1}$. Of the other he says,

I have to report another source of help and saving of labour... Miss Townsend Warner (a pupil of Professor Buck, and a brilliant musician and composer) has for some months been taking lessons from me on the notation of the Mss, in order to give her spare time to the work.

(Carnegie GD 281/38/46)

During the early part of 1917 suggestions for an informal editorial committee were emerging. Among the proposed members, in addition to Stainer and Warner, were the Rev. Dr. Edmund Fellowes, a minor canon at St George's Chapel, Windsor who was currently collecting and scoring English madrigals of the Tudor period, assisted by Cecie Stainer; G. E. P. Arkwright, an eminent scholar of Elizabethan church music, who was currently working on the music of Christopher Tye (c. 1505 - c. 1573); the Rev. A. Ramsbotham, Chaplain of the Charterhouse, who was similarly engaged on the works of Thomas Tomkins (1572 - 1656); and Dr Charles Wood, then professor of composition at the Royal College of Music and an expert on early counterpoint. In a letter Hadow wrote to the Trust's Secretary, he proposed the inclusion of Buck 'whose judgement on matters of taste and form would be invaluable' (Carnegie GD 281/38/46). 
Terry was anxious that Arkwright should join the editorial committee and wrote to encourage him extolling the qualities of his team; of Warner he said,

I have Sylvia Townsend Warner, a most brilliant musician and a pupil of Buck. I only began teaching her the old notation last year, and now she is scoring the stiffest things of the Fayrfax ${ }^{2}$ period that I can find. She is more than clever, in fact she is nothing short of a genius.

(Bodleian, Ms. Mus. C 88: 117)

Terry also revealed to Arkwright that the Trustees had undertaken to issue works of the Tudor composers for a period of five years, at the rate of four volumes a year; in other words, a limit of twenty volumes was imposed. The Trust's Music Standing Sub-Committee (MSS-C) confirmed that Terry should enlist Wood, Ramsbotham, Arkwright, Stainer, Fellowes, Warner and Buck as an Advisory Committee 'on the footing that the work should be voluntary, but that out-of-pocket expenses should be paid: on the other hand, if any definite section of editing work were entrusted to any member...an honorarium should be paid at the conclusion of the work' (Carnegie GD 281/41/225).

By the middle of 1917 Terry was expressing further his confidence in Warner's ability. He argued:

it is very necessary that someone should now go to the Bodleian and Christ Church again to collate some of my scores, the vocal parts of which I do not possess in rotograph... if you approve, I will send Miss Townsend Warner who has plenty of leisure and who is now so far advanced in her study of the old notation that she is able to tackle any kind of manuscript. The work to be done at Oxford she will do as well as I should myself.

(Carnegie GD 281/41/225) 
Warner went to Oxford staying eleven days, for which she claimed $£ 19.5 \mathrm{~s} .9 \mathrm{~d}$ in out-of-pocket expenses (Carnegie GD 281/41/225) and she was to make subsequent visits there for TCM.

Warner also acted as the Minutes Secretary to the editors. Terry, writing to the Trust Secretary later in 1917, remarks, 'I am sending you Miss Warner's draft of the last meeting. Miss Warner's minutes and reports are both shrewd and entertaining (Carnegie GD 281/41/225). Sadly, we are unable to share in Terry's delight as the draft minutes in question weren't appended to the archive file and minutes of the editorial committee's meetings have been lost.

Sundry notes and memoranda in the Trust's archives record actual and intended visits undertaken by all committee members, including Warner. In his annual progress report for 1917 (Carnegie GD 281/41/225) Terry lists the cathedrals whose libraries had been identified for future visits; Warner was to visit Canterbury, Manchester, Peterborough, St Albans and York. There are no records to confirm her going to any of those places. However, she submitted a claim for the period October, 1918 to January, 1919, covering visits to two cathedral cities that weren't listed by Terry:

$1^{\text {st }}$ Class fare to Norwich

£2. 7.9

Cabs

$£$ 3. 0

4 days at Norwich

£6. 0.0

Fare to Salisbury

$£ 1.16 .9$

1 day at Salisbury

£1. 10. 0

Total $£ 11.17 .6$

(Carnegie GD 281/41/225)

Warner certainly visited St Michael's College, Tenbury in Worcestershire. Her detailed visit report, dated September 1917, fits Terry's 'shrewd and entertaining' description. Warner describes the musical miscellany she found in the collection. Some items were of the Tudor period while others were outside it. Of the latter Warner playfully 
wrote, 'a number of operas and oratorios of the classical periwig school, by composers of the school of Grétry' and, 'a large amount of painstaking MS copies of standard works like William Tell and The Last Judgement which might be judiciously consigned to the dust-cart'. More important is her discovery of 'three large part-books copied from some old $\mathrm{MS}^{3}$, (all Carnegie GD 281/41/225).

Appended to Terry's interim report, dated December 1916 , is a typewritten list of fifty-one works by twentyfour different composers, scored by Warner. Handwritten additions to the list, made by Terry, record the type of each work, to indicate the time and effort devoted to each, but without identifying the manuscripts' provenance. He totals her output as ' 7 Masses, 5 Magnificats [and] 39 Motets' (Carnegie GD 281/41/225).

In the same report, Terry informed the MSS-C that it had been found expedient if each member scored specific manuscripts rather than attempting to score the works of a single composer. He mentioned that, 'Miss TownsendWarner (sic) is responsible for the important Sadler ${ }^{4}$ MS. of 729 pages (Bodleian MS. Mus E1 - 5) containing 43 compositions of which I had scored 21. Miss Warner has now completed it'.

Hadow had enquired of Terry, probably orally, for an indication of the relative values of his co-editors. Terry replied in writing to Hadow on 25 May 1918 putting Warner's strengths in perspective:

Fellowes and Ramsbotham are both to be considered 'experts' by reason of their musicianship...both will need a lot of 'editing' as they have only worked on very late music wh[ich] presents no difficulties... and points are always cropping up where they need to be set right in the light of the rules of Mensurable Music. ${ }^{5}$ (sic) Of this they neither of them have much knowledge... Buck is very rapidly becoming acquainted with this [and] consequently can 
score music wh[ich] the other two would find impossible. Miss Warner can now score the earliest kind of music; Miss Stainer is a past "master" in Mensurable (sic) Music Theory, but she hasn't Miss Warner's contrapuntal knowledge. So it amounts to this, that only the Misses Warner [and] Stainer are up to the same kind of highly technical work that I'm employed with [and] the word 'expert' in their case means a great deal more than in the case of Fellowes and Ramsbotham. (You'll quite understand that this is no disparagement of the latter two, but merely that they are engaged on a different kind of work which involves no technical knowledge of the old 'mensurable' rules ${ }^{6}$.)

(Carnegie GD 281/41/224)

It is interesting to note that Buck was described as "very rapidly' getting up to speed at this time and it perhaps suggests that Warner in a role reversal had become instructor to her erstwhile music teacher. In view of their closeness, it seems unlikely that she would not have assisted him.

So confident were Buck and Terry in her mastery of the early notation that they encouraged her to write a highly technical paper - her first - which she presented to the Musical Association, with Buck in the Chair. Warner's paper (Warner, 1919), was well received by its anonymous reviewer in the Musical Times (Vol. 60, 1919, pp.167-8). In another paper that appeared in January 1921, Warner confesses a weakness for trivia and then embarks on serious, illustrated discussion of the inconsequential but often elaborate wordless singing exercises sometimes to be found sandwiched between liturgical compositions in sixteenth-century part-books. Warner maintains they were written by the singers for their own benefit, to strengthen their technique, rather than the composer's (Warner 1921, p.37). 
Further insight into the editors' occupation is contained in Terry's interim report dated April, 1919. He lists his committee's activities in detail: searching libraries for missing part-books that led to Warner's important discovery at Tenbury (although she reported the discovery more than a year earlier); and the commencement of a thematic index to the music scored so far (Carnegie GD 281/41/225).

The thematic index, compiled on hand-written cards, was an expedient to overcome the sixteenth-century practice of composers omitting their names from their works. On each card was the name of the identified composer, the title and type of work, the number of individual voice parts at the editors' disposal and the provenance of each. The initials of each primary editor and their checker were also given. Many of the cards are in Warner's handwriting. Ramsbotham wrote to the Secretary in January 1924 asking for clerical help in indexing the works the editors had scored; he and Warner had become so overwhelmed with proof reading and making corrections, that indexing the music had fallen significantly behind. The Trust sanctioned the $£ 40.00$ needed to pay for it (Carnegie GD 281/38/52).

Citing continual approaches from choirs and singing competition organisers for new works to sing, Terry urged the Trust to print a few carefully selected items in the popular octavo edition for sale. He also suggested that translation into English from the Latin should be speeded up (Carnegie GD 281/38/47), explaining that 'Miss Townsend Warner is doing volume II of Byrd's Cantiones and Ramsbotham is making himself responsible for volume I'. This perhaps comes as a surprise, although the daughter of Harrow School's late, eminent history master could be expected to have learned Latin as a matter of course. Some church music texts would also have been familiar to her already: Warner cites in her poem Tudor Church Music (2008, pp.24-5) the well known and popular short Service set by Orlando Gibbons, Gibbons in $F$, commonly sung in the Anglican Church in the nineteenth century and frequently sung still today. 
Pressure of intense work claimed a casualty. In December 1919 Terry was ordered to take a month's rest having suffered a breakdown, whereupon responsibility for his editorial work passed into the hands of the other editors. Ramsbotham assumed Terry's responsibilities as Secretary of the editorial committee (Carnegie GD 281/41/226). As such, one of his first duties was to meet with the Chairman of the Trust's Executive Committee and Convenor of the MSS-C to report on progress. The memorandum of that meeting confirmed that Wood, Arkwright and Stainer were not serving as editors (Carnegie GD 281/41/227). Ramsbotham submitted a summation of the music scored thus far, excluding Terry's list as it wasn't available:

Prof. Buck

Miss Townsend Warner

72 pieces

Rev. Ramsbotham

82

Dr. Fellowes

218

about 160 pieces.

Such bald statements of fact neglect the painstaking effort devoted to scoring the music, the exacting standards the editors set themselves, and the time taken to close each piece to their common satisfaction. Nor do they reflect the intellectual rigour the editors maintained throughout the demanding procedures. Each score presented by its primary editor was checked against the original by another member of the committee and any alterations were considered by the primary editor and the checker in consultation, with their agreed revised score being circulated to the other editors for their approval (Carnegie GD 281/41/227). Democracy was thus strongly in play, but inevitably often led to arguments.

With the long elapse of time since composition, some of the part-books for a single work could go missing making it necessary for the editors to attempt to track down, not always successfully, alternative manuscripts to produce a complete score. Occasionally they were missing a single voice-part to an important work complete in every other respect. Such a dilemma was overcome by 
the decision to replace it with an imitative substitute. Warner's published diary records her attending a service in Westminster Abbey and rejoicing in the cantus (highest voice) part that she had written for Robert White's Magnificat (1994, p.38).

In 1920 a printed draft of the publisher's Prospectus, setting out the raison d'etre of the ten-volume TCM and its single-work counterparts, designed to induce potential institutional and general subscribers, was sent to the editors for comment. When Ramsbotham returned the draft to the Secretary, with the editors' suggested amendments, a note from Warner was attached that observed, 'I said at the united Committee that I wished to appear as S. Townsend Warner, minus the Miss, and I repeat it now, but if it is not a really essential alteration, and I daresay it isn't, I don't profoundly care. Otherwise it [the Prospectus] is as it should be' (Carnegie GD 281/41/229). The Prospectus was duly published in April 1922. By dis - miss - ing herself, Warner's name appeared alphabetically on its title-page and on all subsequent TCM volumes and associated literature.

Volume I of the scholarly edition was to be devoted to the music of John Taverner, with Terry as its editor, but Ramsbotham was forced to write to the Trust Secretary apologising for delays, and explaining that 'none of the real editing has been done' (Carnegie GD 281/41/235). Warner, Fellowes and Ramsbotham had to take over. Frustration with Terry's unreliability as principal editor had been building since 1919 and it came to a head with a stern letter Buck wrote to rebuke him, dated 2 June, 1921, which his fellow editors all signed. Buck stressed that, "from the beginning you have been no Editor in the true sense at all, that the real work that has been done for this Edition has been done by others' (Carnegie GD 281/41/236). Buck concluded that either the editors or Terry would have to resign: the announcement of Terry's resignation on health grounds was reported at the MSSC's meeting for 15 July, 1921 (Carnegie GD 281/41/235). Terry's ousting from the committee has been fully discussed and expanded on elsewhere, not least by 
Warner herself (Warner, 1947 pp.78-81; Turbet, 1995, pp. 593-600; Turbet, 2000, pp. 433-437). His departure was highly significant because it left Warner as the sole authority on pre-Elizabethan polyphony, to whom the other editors needed to turn for clarification in cases of uncertainty.

Early in January 1922 Ramsbotham was able to write to the Trust saying that the Taverner volume was ready for the engravers save for a biography of the composer and

an appreciation of Taverner's music [to appear as a preface to Volume III] which Miss Warner has in hand; [and] a mass and motet which has given us so much trouble...that we thought it better to examine it still further in full conclave before submitting it for public inspection.

(Carnegie GD 281/38/49)

This latter statement attests to the modus operandi adopted by the editors to ensure editorial integrity.

A national music festival celebrating the tercentenary of William Byrd's death in 1623, to be sponsored by the Trust, was planned for 1923. A committee had been formed, chaired by Hadow, and among its members were the four TCM editors. Hadow urged the Trustees 'to concentrate their Editors' energies in producing as much Byrd (in both editions) as possible' (Carnegie GD 281/38/50). Consequently, Volume II (William Byrd's English Church Music: Part l) came to be published ahead of Volume I. Warner found time to write a short piece exhorting choirs to sing Byrd's music during the tercentenary year (1922, pp.153-154).

Meanwhile revision of Volume I, the first volume of Taverner, continued. The main introductory essay, "A Historical Survey', published without individual attribution, but certainly written by Warner, (Carnegie GD 281/41/239) was approved by Hadow (Carnegie GD $281 / 38 / 50$ ) and, since she had become expert, it is beyond 
doubt that she compiled the preface concerning sixteenthcentury notation. Additionally, the editorial preface, which pays tribute to previous collectors of Tudor church music, may similarly be attributed to Warner on stylistic grounds. These pieces are highly significant because they inform the whole ten volume set. They are pragmatic, written to establish context, scope and method, where more imaginative prose would have been out of place.

When Volume I had been published it prompted a captious review, written by another scholar and eminent writer on English polyphony, Dom Anselm Hughes from Pershore Abbey (1924a, pp.145-154). While praising the TCM enterprise overall, where fault could be found Hughes found it. He identified clumsy editorial mistakes and judgemental errors in the body of the work; and in Warner's 'Historical Survey', he discerned omissions, misattributions, instances of inaccuracy and mistaken emphasis. Since the prefaces were a shared responsibility of the whole team and of Hadow, who endorsed them, Hughes's strictures cannot be laid before Warner alone. Warner nonetheless responded independently and without reference to $T C M$ or the other editors, although Hughes would obviously have known of her affiliation, in an elegant, controlled and signed essay on the apprehensions and misgivings, the presuppositions and temptations, the cardinal rules and pragmatisms, of an editor treading a path through sixteenth-century polyphony; the raw material, she said, was at best the work of copyists and not works autographed by their composers (Warner 1924, p.160). She cleverly sidestepped Hughes's specific accusations preferring to affirm the work of an editor as 'a form of trusteeship' (p.155) where good faith in the editorial method has to be accepted.

By the close of 1924, TCM, Volume III, John Taverner, Part II, had been published containing Warner's personal assessment of Taverner's music. This could not have been written without thorough knowledge and understanding of the composer's music, his confidence in innovation and his place in the wider musical context of the early sixteenth century. 
With the Trustees continually showing their concern at the slow rate of progress, by June 1925 agreement was reached with the editors to handle succeeding volumes concurrently, rather than one at a time. This must have involved each of the editors in additional concerted work; many long hours engrossed, both individually and in committee, in seemingly endless amounts of checking and rechecking galley proofs from the printers. With Volume $\mathrm{V}$ (Robert White, d. 1574) now published and Volume VII (William Byrd, Gradualia Books I and II) proof-read, Ramsbotham informed the MSS-C in April 1926, that he had almost completed Volume VI (Thomas Tallis 1505 1585), but the immediate delay was because 'Miss Warner is away... and has taken with her a certain amount of text to which she is giving the necessary final polish' (Carnegie GD 281/38/54).

Examination of the preliminary material for the Tallis volume reveals little of the polish that typifies her style of writing. However, the appreciation essay to the Robert White volume, simply headed 'His Work' could have been written only by Warner. The audacious opening, for example, with its strong allusion to Sir Thomas Browne's Urn Burial, reads,

There is a comfortable belief that time and change try reputations by some infallible touchstone; that the worthiest will survive; and that the iniquity of oblivion does not scatter its poppy quite so blindly after all. This belief is sharply challenged by the case of Robert White.

(Warner 1926b, pp. xiv-xv).

None of the other editors would have risked such irrepressible exuberance for the composer whose- music profoundly touched her spirit. Further evidence of Warner's literary presence can also be found in the introductory musical assessment in Volume IV (Orlando Gibbons $1583-1625$ ) where her imaginative prose style is equally plain to see (Warner, 1926a, p. xi) 
While one may confidently say Warner wrote introductory narratives to several of the $T C M$ volumes, it was Fellowes who was tasked with researching and compiling composers' biographies. He had pertinent previous practical experience in genealogical research which he had already applied when writing the lives of the madrigal composers (Fellowes, 1946, pp.203-204).

The Trust's Annual Report for 1928 carries the statement, 'The Tudor Music Quarto Edition has been completed so far as the Editors are concerned; eight volumes have appeared, and the last two are to be published by the end of 1929' (Carnegie GD 281/38/54). Volumes IX (William Byrd. English Church Music: Part II) and X (Hugh Aston; John Marbeck; and Osbert Parsley) were published in the first quarter of 1929. Funding for a further ten volumes of $T C M$ had been refused outright by the Trust (Carnegie GD 281/38/52). However, there was a large quantity of rotographed music awaiting scoring, and a significant number of scored compositions that were intended for future volumes. Of the octavo edition, fifty works had been published, and some reprinted, of which Warner had edited seven. The series proved so popular that its sales covered production costs and went on into profit.

Fellowes attempted to find alternative financial sponsorship in America for ten more $T C M$ volumes and the editors continued to score and meet to discuss their work but, although he was promised funding, 1929 was not a propitious time for financial speculation and the scheme foundered (Fellowes, 1946, p.128).

Warner's published and unpublished diary entries provide us with valuable evidence of her musicological work as the $T C M$ project drew to its close, and of the related work she undertook subsequently. For example, she contributed significantly to the revision of $\mathrm{H}$. E. Wooldridge's chapters on polyphony in the 1932 revision of the second volume of the Oxford History of Music, under Buck's general editorship, rewriting chapter III, The English School (Wooldridge, 1932 pp. 157-196), and contributing significantly to chapter IV (Wooldridge, 
1932, pp.206-232). For these she was able to cite works from $T C M$ and illustrate them with the newly scored music, including settings by Byrd, Tallis, White and Taverner. Warner's diary entry for 21 September, 1929, is most apposite:

A slightly grubby day, dealing with Wooldridge. In the evening I finished the text, and began on the illustrations. Looking for one from ...[Byrd's] Gradualia I happened upon Quotiescunque manducabitis; and at the bass entry on mortem Domine I was cast into such a rapture of knowing the man's mind that I was ready to count all the damnations of scholarship as nought for the sake of that one passage alone.

(Warner, unpublished diaries)

Her moment of catharsis is so lucidly encapsulated here that the reader exults in harmony on making its acquaintance.

Warner also wrote and signed a substantial and erudite chapter on notation for a new introductory volume to that revision of the Oxford History of Music (1929). Furthermore, to read the editor's preface to the Introductory Volume is to identify such convincing evidence of Warner's turns of phrase and lateral thinking as to suggest that if she didn't write it herself, alone, she played a strong hand in revising it for Buck (Buck 1929, pp. $v-x)$.

In summary, Warner was pre-eminent over her fellow TCM editors. Unlike them, she was not in full employment elsewhere and could dedicate abundant time and energy to the project for twelve years, despite becoming during its lifetime a published writer of poetry and fiction as well as the articles that were spawned as by-products of the TCM endeavour. Because of her flair for expressing herself in words she was given the task of compiling supporting narratives to some of the volumes and, more important, the freedom to write imaginatively 
where the scope of the piece allowed it. Without the card index at Senate House Library, the works she scored for the octavo series, her diary entries and the occasional Trust Committee minutes for confirmation, it would be difficult to identify with any degree of certainty the musical compositions Warner personally edited, many items having been scored in committee. But, from what has emerged from researching this paper we know that Warner's contribution to the monumental Tudor Church Music was comprehensive, prodigious and major. That she contributed so significantly to such an eminent collection of hitherto unknown church music, to enable general access to a wealth of prominent choral music from a school unequalled in any age or any country for its originality and accomplishment, does her reputation enormous credit and is deserving of celebration.

\section{NOTES}

1. Daughter of the composer, Sir John Stainer who, together with her brother, scored Stainer's Early Bodleian Manuscripts, 1901.

2. Robert Fayrfax (1464 - c. 1521) English composer at the courts of Henry VII and Henry VIII

3. Known as the Tenbury Manuscript it contains, among several other works, English sixteenth- century part-books not found anywhere else, including works of Byrd and Taverner.

4. John Sadler (b. 1513) was a music copyist. The Manuscript held in the Bodleian Library contains his copies made in 1585 of the part-books of sacred motets by several Tudor composers, such as Byrd, Tallis, Taverner and White.

5. Polyphonic notation had been evolving continually since its beginnings in the twelfth century, when it developed out of Plainsong, through to the present. It is to be understood that the notation of the Elizabethan age was simpler and less difficult to interpret than its Henrician precursor.

6. Mensural music (musica mensurata) was a mediaeval term that has survived for music where each note type has 
a specific time value, as distinct from Plainsong (musica plana) which is sung in free rhythm.

7. Often referred to as the Eton Choirbook. Written between 1490 and 1502 for use by the choristers at Eton College, it contains 50 complete works and many fragments of others.

\section{WORKS CITED}

BODLEIAN ARCHIVES, files Ms. Mus. C 88: 117 and Ms. Mus E1 - 5. The Bodleian Library, Oxford.

BUCK, P. et al. eds. (1922-1929) Tudor Church Music. Oxford: Oxford University Press. 10 vols.

BUCK, P. ed. (1929) Oxford History of Music. Introductory Volume. London: Oxford University Press.

CARNEGIE UNITED KINGDOM TRUST Tudor Church Music archives files GD 281/41/224 - 46; archive files of the Standing Music Sub-Committee which oversaw the project at GD 281/38/46 - 58. National Archives of Scotland, Edinburgh.

FELLOWES, E. (1946) Memoirs of an Amateur Misician. London: Methuen.

HUGHES, A. (1924a) Review: 'Sixteenth Century Service Music', Music and Letters, Vol.5, No.2, pp. 145 154.

TERRY, R.R. (1920) 'Discoveries of Tudor Music' Part I, The Sackbut, v.1, No.4, pp.184-8.

TURBET, R. (1995) 'An Affair of Honour', Music and Letters, Vol. 76, No.4, pp.593-600. (2000) 'A Monument of Enthusiastic Industry', Music and Letters, Vol. 81, No. 3, pp.433 - 437.

WARNER, S.T. (1918) Letter to Herbert Howells. Herbert Howells, Archive, Royal College of Music, London. (1919) 'The Point of Perfection in XVI Century Notation', The Proceedings of the Musical Association, vol. XLV, February 1919, pp. $67-74$.

(1921) 'An Aspect of Tudor Counterpoint', Music 
and Letters Vol. 2, No. 1, pp. 35 - 49.

(1922) 'Byrd Tercentenary Festival', British Music

Society Bulletin, Vol. 4, No.9, pp. 153 - 154.

(1924) 'Doubting Castle', Music and Letter's,

Vol. 5, No.2, pp. 155 - 168

(1926a) Introduction, 'Orlando Gibbons', Tudor'

Church Music, Vol. IV: Orlando Gibbons 1583 1625 ed. Percy Buck et al. Oxford: Oxford

University Press, 1926 p. xi

(1926b) 'His Work', Tudor Church Music, Vol. V

Robert White d.1547 ed. Percy Buck et al. Oxford:

Oxford University Press, pp. xiv - xv

(1947) Review: Memoirs of an Amateu Musician

by Edmund H. Fellowes. Music and Letters,

Vol. 28, No.2, pp. $78-81$.

(1994), The Diaries of Sylvia Townsend Warner.

Ed. C. Harman. London: Chatto \& Windus.

(2008), New Collected Poems. Ed. Claire Harman.

Manchester: Carcanet Press.

Unpublished diaries, The Sylvia Townsend

Warner Archive, Dorset County Museum,

Dorchester.

WOOLDRIDGE, H. (1932) The Oxford History of Misic, Vol. II The Polyphonic Period. Part II Method of Musical Art 1300-1600. $2^{\text {nd }}$ edition, revised by P. Buck. London: Oxford University Press. 2 vols. 